Berkala Ilmu Perpustakaan dan Informasi, Vol. 15, No. 1, Juni 2019, Hal. 87-100 DOI: 10.22146/bip.31764

ISSN 1693-7740 (Print), ISSN 2477-0361 (Online)

Tersedia online di https://jurnal.ugm.ac.id/bip

\title{
Bibliotherapy dalam menumbuhkan sikap optimis pasien
}

\author{
Rully Khairul Anwar, Diah Sri Rejeki, Ute Lies Siti Khadijah, Sukaesih ${ }^{1}$ \\ ${ }^{1}$ Program Studi Ilmu Perpustakaan Universitas Padjadjaran \\ e-mail:diahsr@gmail.com
}

\section{Naskah diterima: 28 Desember 2017, direvisi: 22 Agustus 2018, disetujui: 24 Oktober 2018}

\begin{abstract}
ABSTRAK
Pendahuluan. Pustakawan mempunyai peran dalam menumbuhkan sikap optimistis melalui Terapi buku/bibliotheraphy pada pasien yang menghadapi suatu penyakit. Penelitian tentang Bibliotherapy dalam Menumbuhkan Sikap Optimis Pasien: Studi Quasi-Eksperimental terhadap Pasien di Berbagai Rumah Sakit di Indonesia ini bertujuan untuk mengetahui manfaat dari bibliotheraphy untuk kesehatan terutama dalam menumbuhkan sikap optimis pasien.

Metode Penelitian. Metode penelitian ini menggunakan quasi-eksperimental. Pengumpulan data melalui observasi dengan pasien, wawancara mendalam dan studi literatur. Sumber datanya adalah pasien rumah sakit dan pakar akademik di bidang bibliotheraphy.

Analisis Data. Data penelitian menggunakan analisis kualitatif.

Hasil dan Pembahasan. Penelitian ini terdapat 5 tahapan pelaksanaan bibliotherapy terhadap pasien yakni: (1) pasien termotivasi oleh pustakawan dengan melakukan permainan yang melibatkan pasien dengan nasihat positif. (2) Pustakawan menyuruh pasien untuk membaca materi yang telah disiapkan. (3) Pustakawan memberikan waktu pasien untuk merenungkan materi yang telah dibaca. (4) Pustakawan melakukan diskusi dengan pasien tentang materi yang telah dibaca. (5) Pustakawan mengevaluasi dengan mendengarkan kesimpulan dari pasien.

Kesimpulan dan Saran. Biblioterapi dapat berguna untuk meningkatkan kesehatan, terutama dalam meningkatkan sikap optimis pasien dalam menghadapi penyakitnya.
\end{abstract}

Kata Kunci: Biblioterapi; Pasien; Sikap optimis

\section{ABSTRACT}

Introduction. One of the librarians' role is to improve the feeling of optimistic through bibliotheraphy on patients. This paper focuses on bibliotherapy to improve patients' optimistic attitude. This study aims to understand the benefits of bibliotheraphy from patients' health perspectives.

Data Collection Method: This research used a quasi-experimental approach. Data collection was conducted through patients observation, in-depth interviews and literature study. Our study population was patients in several hospital as well as involving academic experts in the field of bibliotheraphy.

Analysis Data: The data was analysed based opn qualitative approach.

Results and Discussions: There were 5 implementation stages of bibliotherapy to the patients: (1) Patients were motivated by the librarian with the games involving patients with positive advice (2) The librarian asked the patients to read the prepared material (3) The librarian gaves patients some time to reflect on their reading materials (4) The librarian discussed with patients about the reading materials (5) the librarian evaluated by listening to the patients.

Conclusion: Bibliotherapy can be useful for health improvement, particularly to improve optimistic attitude of patients in dealing with their disease.

Keyword: Bibliotheraphy; patients; optimistic attitude 


\section{A. PENDAHULUAN}

Kesehatan merupakan hal yang sangat penting dalam kehidupan manusia. Tanpa kesehatan, orang tidak akan dapat melaksanakan kegiatan dengan baik. Banyak orang melakukan ritual untuk menjadi sehat misalnya, olahraga, pengaturan pola makan, pola tidur dan bersosialisasi dengan masyarakat. Namun itu semua tidak menjamin seseorang akan terus hidup sehat, kadang-kadang penyakit ini datang ketika kondisi seseorang sedang dalam keadaan stres karena semua kesulitan dan tekanan hidup. Untuk itu, perlu setiap individu perlu menjaga kesehatan mentalnya masingmasing. Kesehatan mental menurut Manwell et al. (2015) adalah The core concepts of mental health identified were mainly individual and functional, in that they related to the ability or capacity of a person to effectively deal with or change his/her environment. Artinya konsep dari kesehatan mental terletak pada individual dan fungsional yang mana masih berhubungan dengan kemampuan atau kapasitas seseorang dalam menangani atau mengubah lingkungannya. Ketidakmampuan seseorang dalam memecahkan masalah sehingga dapat menimbulkan stres yang berlebihan menjadikan kesehatan mental individu tersebut menjadi lebih rentan. Seseorang dikatakan memiliki mental yang sehat jika dia terlindung dari gejala penyakit mental dengan cara menyelaraskan fungsi-fungsi jiwanya. Definisi ini menunjukkan bahwa fungsi jiwa sebagai pikiran, perasaan, sikap, pandangan dan keyakinan, yang dimana semua hal tersebut harus saling mendukung dan bekerja sama untuk menciptakan keharmonisan hidup untuk menghindari kecemasan dan konflik batin. Jika seseorang sedang dalam keadaan sakit mental, maka diupayakan untuk mencari metode penyembuhan yang paling efektif. Ilmu kesehatan semakin berkembang, teknik penyembuhan bisa dilakukan dengan cara medis atau alternatif, salah satunya adalah teknik penyembuhan dengan pola pikir positif dan sikap optimis. Optimisme adalah sikap yang selalu mengharapkan hal-hal baik dan hasil yang baik.
Menunjukkan sikap positif akan memunculkan banyak manfaat kesehatan, mulai dari meningkatkan sistem kekebalan, memunculkan perasaan optimis, dan menimbulkan perasaan bahagia. Seperti yang dilansir dalam surat kabar online Kompas.com mengungkapkan bahwa terdapat beberapa keuntungan dalam berpikir positif, antara lain: (1) Berpikir positif membantu dalam mengatasi situasi stres, mengabaikan pikiran negatif, mengganti pikiran pesimis menjadi optimis, mengurangi kecemasan dan mengurangi stres. (2) Ketika mengubah pikiran negatif menjadi positif maka akan menimbulkan rasa ketenangan dan kedamaian, sehingga tidak akan mengalami gangguan saat tidur, tidak merasakan ketegangan otot, kecemasan, dan kelelahan. (3) Dapat lebih percaya diri dengan tidak mencoba menjadi orang lain. (4) Dapat mengambil keputusan yang benar, karena adanya sikap positif dari ketenangan dalam menghadapi masalah. (5) Dapat meningkatkan fokus dalam menghadapi masalah. (6) Sikap positif dapat mengarahkan atau mengatur kehidupan pribadi menjadi lebih baik. (7) Dapat mengatur waktu lebih baik, sehingga segala kegiatan dapat terorganisir. (8) Orang yang berpikir positif mempunyai kemampuan untuk menarik banyak teman. (9) Menjadi pemberani, karena ketakutan berasal dari sikap negatif. (10) Memiliki sikap positif dapat mengantisipasi hidup bahagia (Chandra, 2011).

Seseorang yang memiliki sikap optimis bisa menghadapi situasi tidak menyenangkan dengan cara positif dan produktif. Jadi dia tidak hanya akan memikirkan penyakitnya, tapi dia bisa mendistribusikannya dengan kegiatan positif sehingga penyakit ini dapat disembuhkan dengan cepat. Seperti yang telah dialami oleh Charlotte Newman dia adalah seorang wanita 23 tahun yang menderita kanker tulang. Pertama kali dia tahu, dia sangat terkejut dan berlari keluar dari ruangan dokter. Dia menangis dan orang tuanya berusaha menenangkannya. Hal ini terjadi lebih dari lima bulan yang lalu, sampai Charlotte bergabung di Teenage Cancer Trust (TCT). Setelah bergabung dengan kelompok tersebut Charlotte menjadi lebih optimis dan 
ingin menjalani serangkaian perawatan dengan semangat karena dia ingin sembuh dari penyakitnya (Gil, 2013). Ada juga kisah sukses melawan kanker payudara yang dihadapi oleh salah satu aktris Indonesia Rima Melati. Dia mengatakan gaya hidup yang tidak sehat adalah salah satu pemicu sel kanker pada payudaranya. Saat melakukan proses penyembuhan melalui kemoterapi yang mengakibatkan rambut rontok dan rasa sakit yang luar biasa, pada awalnya dia merasa lelah dan ingin menyelesaikan proses pengobatan, tetapi karena dukungan dari keluarga dan diberi motivasi positif akhirnya dia memiliki keberanian untuk menjalani proses penyembuhan. Sampai hari ini ia dinyatakan sepenuhnya pulih dari kanker payudara karena sikap optimisnya.

Contoh-contoh tersebut menunjukkan bahwa sikap optimistis dapat membantu proses penyembuhan seseorang dalam menghadapi penyakit. Berikut adalah cara untuk menumbuhkan sikap optimis yaitu: seseorang harus menikmati semua peristiwa baik atau buruk dan berpikir bahwa ada manfaat di balik semua yang telah terjadi, seseorang harus mencari lingkungan yang positif terutama dalam memilih teman. Pilihlah teman yang selalu optimis dan dapat memberikan pengaruh yang baik, melalui bibliotherapy yaitu teknik terapi dengan membaca buku, mengambil hal positif dari buku tersebut, merenungi lalu mengimplementasikan hal positif tersebut dalam kehidupannya.

Dalam bibliotherapy ini seseorang menggunakan buku untuk mencari tahu hal-hal positif yang bisa diimplementasikan dari buku tersebut. Prosesnya adalah fasilitator (pustakawan) dan peserta (pasien) bertukar pendapat tentang buku yang diberikan fasilitator untuk peserta. Penggunaan terapi ini untuk proses penyembuhan pertama kali muncul di Yunani, selain itu biblioterapi mempunyai kemampuan terapeutik yang dapat meningkatkan kesehatan mental (Herlina, 2013). Jadi pustakawan membantu pasien untuk menemukan solusi melalui buku yang dibacanya. Hal tersebut didasarkan pada keyakinan bahwa membaca dapat mempengaruhi sikap, perilaku dan perasaan.
Pendekatan membaca buku digunakan untuk mempengaruhi perilaku seseorang untuk membuat perubahan dalam pemikiran disebut bibliotherapy rasional. Dalam penelitian ini penulis akan fokus pada bibliotherapy sebagai cara untuk menumbuhkan sikap optimis pada pasien yang menderita suatu penyakit. Bibliotherapy bertujuan untuk membantu seseorang memecahkan masalah melalui bukubuku literatur dan sumber daya lain yang berkaitan dengan pola pikir dan emosional untuk membantu mengubah perilaku seseorang untuk mencapai apa yang dia inginkan.

Keberadaan perpustakaan di rumah sakit sebenarnya bisa sangat membantu pasien dan civitas rumah sakit untuk memenuhi kebutuhan membaca. Selain itu, perpustakaan juga bisa menjadi penyembuhan mental melalui koleksi buku. Pasien dengan kondisi fisik yang lemah, kebanyakan dari mereka memiliki pola pikir yang buruk cenderung pesimis dan memiliki tingkat stres yang tinggi, misalnya, memikirkan biaya rumah sakit, memikirkan kondisi kesehatan yang memburuk, memikirkan kegiatan rutin yang telah lama ditinggalkan, dan lain-lain. Pola pikir tersebut dapat menjadi hambatan yang mempengaruhi kesembuhan pasien, untuk mengatasi hambatan tersebut pasien membutuhkan pendampingan untuk berbagi masalah yang dialaminya. Saran terkadang tidak memiliki efek bahkan kadang kala membuat kondisi seseorang semakin parah karena dia merasa tidak ada yang mengerti perasaannya. Pendampingan dalam hal ini bisa menjadi solusi karena dalam pendampingan terdapat kegiatan refleksi diri dan kegiatan diskusi. Pendampingan terbaik yang bisa dilakukan pustakawan untuk pasien adalah melalui bibliotherapy. Buku bisa dibaca berulang-ulang sehingga pembaca dapat menemukan solusi untuk masalahnya. Dengan bibliotherapy, pustakawan terutama pustakawan di rumah sakit bisa lebih proaktif dalam membantu untuk menyembuhkan pasien.

Berdasarkan penjelasan tersebut, penulis ingin mengetahui manfaat dari keberadaan perpustakaan di rumah sakit dan khususnya untuk mengetahui manfaat dari bibliotherapy bagi pasien sehingga bibliotherapy dapat 
digunakan sebagai desain pelayanan permanen di perpustakaan rumah sakit. Selama penulis tahu, perpustakaan rumah sakit hanya digunakan sebagai tempat untuk menyimpan dan meminjam buku, dengan penelitian ini penulis berharap perpustakaan rumah sakit dapat mempertimbangkan dengan baik manfaat pelaksanaan bibliotherapy untuk menumbuhkan sikap optimis pada pasien.

Penelitian ini merupakan penelitian baru, orisinal dan belum pernah dipublikasikan sebelumnya. Sejauh ini, penelitian yang pernah dilakukan menjelaskan mengenai bibliotherapy yang dapat mengembangkan karakter bertanggung jawab, meningkatkan pemahaman mengenai labelling negatif pada siswa SD, dan lain-lain. Sedangkan dalam penelitian ini difokuskan pada bibliotherapy yang dapat menumbuhkan sikap optimis pada pasien. Adapun pasien yang menjadi informan dari penelitian ini adalah orang-orang yang memiliki tingkat kekhawatiran tinggi terhadap masa depan yang belum dialaminya, misalnya wanita hamil yang selalu merasa ketakutan dan khawatir berlebihan akan kematian setelah melahirkan karena berdasarkan pengalaman saudaranya yang meninggal setelah melahirkan anaknya. Lalu ibu menyusui yang mengalami baby blues syndrome sehingga tidak mau menyusui anaknya, bapak yang pernah mengalami gejala stroke yang mempunyai kekhawatiran berlebih sehingga tidak melakukan aktivitas seperti biasanya. Melalui bibliotherapy, pasien-pasien tersebut dapat menurunkan tingkat kekhawatiran yang berlebihan terhadap masa depan yang belum dialaminya.

\section{B. TINJAUAN PUSTAKA}

Beberapa penelitian terdahulu mengenai bibliotherapy, seperti yang dilakukan Dewi \& Prihartanti (2014) mengenai metode bibliotherapy dan diskusi moral untuk pengembangan karakter tanggung jawab dengan hasil penelitian yang menjelaskan bahwa skala karakter tanggung jawab memiliki lima faktor yaitu: kehati-hatian, orientasi pada tugas, keunggulan, kegigihan dan komitmen. Berdasarkan uji hipotesis, diperoleh hasil bahwa metode biblioterapi dan metode diskusi dilema moral berpengaruh terhadap peningkatan karakter tanggung jawab pada mahasiswa. Penelitian lainnya yang dilakukan oleh Anggraeni (2018) mengenai biblioterapi untuk meningkatkan pemahaman labelling negatif pada siswa SMP menjelaskan Hasil analisis menunjukkan bahwa nilai $\rho=0.018$ lebih kecil dari $\alpha=0.05$, berdasarkan hasil ini maka Ho ditolak dan Ha diterima. Hipotesis penelitian ini yaitu "biblioterapi dapat meningkatkan pemahaman labelling negatif pada siswa kelas VII-D di SMP" dapat diterima, sehingga dapat disimpulkan bahwa biblioterapi efektif untuk meningkatkan pemahaman labelling negatif pada siswa kelas VII-D di SMP. Perbedaan penelitian ini dengan penelitian bibliotherapy lainnya terletak pada hasil akhir yang ingin dicapai melalui biblioterapi, yakni sikap optimis pada pasien.

Buku merupakan salah satu media untuk menambah pengetahuan, informasi dan hiburan. Selain itu buku juga dapat menjadi media terapi pada pasien dengan gangguan mental seperti ketakutan, kecemasan dan stres. Seperti yang dikatakan Plato yang diteruskan oleh Rush dan Galt di 1815-1853, melalui eksperimen medis, menyimpulkan bahwa buku yang digabungkan dengan proses mentoring dapat menciptakan hubungan yang hangat, menjelajahi gaya hidup dan menambah pengetahuan. Bibliotherapy telah dikenal sejak zaman Yunani kuno. Ide pemanfaatan bahan bacaan sebagai media terapi dipicu oleh Plato (Jack \& Ronan, 2008).

Salah satu fungsi literatur juga dapat digunakan sebagai alat untuk membantu menghadapi persoalan setiap individu baik literatur jenis fiksi atau non-fiksi (Novita, Sugiharto, \& Ani, 2017). Selain itu seseorang juga dapat secara aktif menggunakan bibliotherapy untuk membantu mengatasi masalahnya serta membantu orang tersebut mendapatkan kekuatannya kembali (Maydiana \& Siswanto, 2012).

Bibliotherapy berasal dari biblion (buku) dan teraphy (penyembuhan). Buku dapat mengubah pandangan negatif menjadi positif sehingga dapat mengubah pola pikir seseorang. Rumah Sakit adalah tempat berkumpulnya 
orang-orang yang menderita penyakit dan mayoritas dari pasien tersebut memiliki pola pikir negatif yang akan mempengaruhi penyembuhan pada pasien. Maka dari itu selain perawatan medis, perlu dilakukan bibliotherapy, yakni terapi menggunakan media buku yang disertai dengan pustakawan dan dipantau oleh dokter yang menangani pasien tersebut dalam menyembuhkan penyakit agar proses penyembuhan dapat berjalan lancar dan cepat.

Schetmant (2009) menyatakan bahwa bibliotherapy entails the use of literature for therapeutic purposes and it includes listening to stories and poems, watching films, and looking at pictures. It is a playful, engaging, and fun process, jelasnya bahwa biblioterapi merupakan penggunaan literatur untuk tujuan pengobatan dengan cara mendengarkan cerita, menonton film dan melihat gambar (Eliasa \& Iswanti, 2014). Sedangkan, Magaji \& Shem (2016) dalam penelitiannya menjelaskan bahwa bibliotherapy is one of the solutions to emotional disturbance and as a problem-solving skill of counsellors, artinya biblioterapi merupakan salah satu solusi untuk gangguan emosional dan keterampilan yang dimiliki konselor dalam memecahkan permasalahan.

Menurut Yuliawati (2011) intervensi bibliotherapy dapat dikelompokkan menjadi empat tingkatan, yaitu intelektual, sosial, perilaku dan emosional. Pertama, pada tingkat intelektual pasien bisa mendapatkan pengetahuan tentang perilaku yang dapat memecahkan masalah dan kemudian pasien mungkin menyadari ada banyak pilihan dalam menangani masalah. Kedua, pada tingkat sosial pasien dapat mengasah kepekaan sosial mereka, melalui membaca pasien menjadi lebih tahu tentang orang-orang yang memiliki masalah yang sama dengan dia, secara tidak langsung, hal itu akan memperkuat pasien mental dan kuat dalam menghadapi masalah. Ketiga, tingkat perilaku pasien akan mendapatkan kepercayaan diri untuk berbicara tentang masalah untuk orang lain. Keempat, pada tingkat emosional, pasien akan melakukan refleksi diri yang akhirnya menyadari apa solusi yang terbaik baginya.
Pittman (2017) Pada tahun 1918, Library War Service menempatkan pustakawan di rumah sakit militer untuk memberikan layanan khusus bagi yang sakit dan terluka. Pada 1919, berdiri perpustakaan di rumah sakit dengan memiliki koleksi sekitar 3.500 tanpa memiliki pustakawan yang berdedikasi. Koleksi-koleksi yang ada memuat informasi mengenai perang, karir yang bisa diambil pasca perang, novel non fiksi, dan lain-lain. Buku-buku yang terdapat di rumah sakit dapat berfungsi untuk mendidik dan menghibur namun di sisi lain dapat pula berfungsi sebagai obat. Pustakawan pada zaman perang tersebut pernah mengungkapkan bahwa: "Stories are sometimes better than doctors", jelasnya sebuah cerita yang menarik akan sering menenangkan dan dapat memulihkan pikiran.

Jadi bibliotherapy telah dilaksanakan sejak lama dan jelas ada manfaat kesehatan. Bahkan sebagian besar orang telah menerapkan terapi membaca. Misalnya ketika seseorang melakukan pencarian identitas (mencari jati diri), orang biasanya membaca buku-buku tentang pengembangan pribadi untuk menentukan identitas mereka, atau kadangkadang ketika seseorang berada dalam keadaan sedih dan orang tersebut membaca buku untuk menghibur diri yang secara tidak langsung dapat membantu mengurangi kesedihannya. Tujuan dari bibliotherapy ini adalah untuk menemani seseorang yang dalam keadaan emosi karena masalah yang dihadapinya dengan memberikan buku dengan topik yang sesuai. Cerita dalam buku tersebut dapat membantu mereka untuk merefleksikan diri dan mengambil pelajaran yang dapat memutuskan solusi terbaik atas permasalahan mereka. Oleh karena itu dianjurkan agar setiap rumah sakit memiliki perpustakaan yang tidak hanya digunakan sebagai tempat untuk menyimpan dan meminjam buku saja, tapi perlu ada layanan bibliotherapy yang bisa dilakukan oleh pustakawan yang bekerja sama dengan dokter.

Di Indonesia, bibliotherapy telah digunakan oleh psikiater tanpa melibatkan perpustakaan dan pustakawan, contohnya di Rumah Sakit Dr. Cipto Mangunkusumo (Darmawan, Rohanda, \& Kusnandar, 2012). Hal ini terjadi karena ruang lingkup kerja 
pustakawan masih dianggap sempit, mayoritas mereka menganggap bahwa pekerjaan pustakawan sebatas menjaga buku dan melayani pengunjung saja. Oleh karena itu dalam artikel ini menunjukkan bahwa ternyata pustakawan dapat bekerjasama dengan siapa saja bahkan dengan dokter sekalipun dalam memberikan bimbingan untuk menyembuhkan pasien melalui bahan bacaan. Pustakawan menyediakan bahan bacaan dan psikiater mencari penyebab serta teknik pengobatannya (Agustina, 2014).

Bibliotherapy merupakan pendekatan terapeutik yang menggunakan literatur untuk mendukung kesehatan mental, serta teknik pengobatannya fleksibel dan hemat biaya dan dapat digunakan untuk melengkapi jenis terapi lainnya ("Bibliotherapy: Online Dictionary for Library and Information Science," n.d.). Metode pengobatan ini sangat dianjurkan, terutama untuk orang dengan stres, depresi, kecemasan, dan pasien yang sulit untuk mengungkapkan permasalahannya secara verbal. Olsen (2007) menyarankan lima tahap penerapan bibliotherapy, baik dilakukan secara individu maupun kelompok, antara lain dapat dilihat pada Gambar 1:

a. Motivasi: Pustakawan dapat memberikan kegiatan pengenalan sebelum memulai terapi, misalnya dengan memberikan motivasi untuk mendapatkan peserta untuk terlibat aktif dalam kegiatan terapi.

b. Baca buku: Pustakawan memberikan waktu bagi pasien untuk membaca buku yang telah disiapkan oleh pustakawan. Adapun buku tersebut adalah yang mudah dimengerti dan berisi kalimat-kalimat yang positif yang dapat mempengaruhi pembaca. Dalam hal ini pustakawan telah menguasai isi dan tujuan dari buku tersebut.

c. Refleksi diri: Pustakawan memberikan waktu bagi pasien untuk merefleksikan materi yang telah dibaca. Dalam kegiatan ini pustakawan memberikan waktu maksimal 30 menit dan pasien diperbolehkan untuk 'menggarisbawahi' poin yang kurang dipahami atau bahkan kalimat dalam sebuah buku yang mewakili perasaan atau keadaan yang dialami sebagai bahan untuk diskusi.

d. Diskusi: kemudian pustakawan mengadakan forum diskusi terbuka, melalui ini pasien dan pustakawan dapat bertukar pandangan tentang ide-ide yang datang setelah membaca buku.

e. Evaluasi: Tahap terakhir adalah evaluasi. Pada tahap ini, evaluasi dapat dilakukan oleh seorang dokter yang bertujuan untuk mengetahui perkembangan dari sebelum dan setelah terapi. Jika ada perubahan pola pikir dan perilaku ke arah yang positif, maka terapi dinyatakan berhasil.

Selama kegiatan pendampingan berlangsung, pustakawan juga harus melakukan pengamatan, berbicara dengan keluarga pasien, berbicara dengan dokter yang menangani pasien tersebut untuk mengetahui dengan pasti perubahan yang terjadi pada pasien. Keterampilan yang harus dimiliki oleh seorang pustakawan dalam melakukan bibliotherapy dapat menentukan subjek sebuah buku yang cocok untuk digunakan dalam terapi, kemampuan diskusi, kemampuan untuk mendengarkan masalah pasien, dan kemampuan untuk membuat laporan tertulis tentang proses bibliotherapy dari awal sampai akhir. Sehingga pustakawan dapat melakukan akuisisi dan menentukan buku mana yang digunakan untuk proses terapi. Pustakawan dalam menentukan buku untuk terapi harus menyesuaikan dengan kemampuan intelektual pasien.

\section{METODE PENELITIAN}

Kriteria informan dalam penelitian ini adalah orang-orang yang memiliki tingkat kekhawatiran tinggi terhadap masa depan yang belum dialaminya, misalnya wanita hamil yang selalu merasa ketakutan dan khawatir berlebihan akan kematian setelah melahirkan karena berdasarkan pengalaman saudaranya yang meninggal setelah melahirkan anaknya. Lalu ibu menyusui yang mengalami baby blues syndrome sehingga tidak mau menyusui anaknya, bapak yang pernah mengalami gejala stroke yang mempunyai kekhawatiran berlebih 
sehingga tidak melakukan aktivitas seperti biasanya. Informan yang dipilih merupakan pasien dari beberapa rumah sakit dengan status pasien rawat jalan, diantaranya pasien Pusat Kesehatan Masyarakat wilayah Rancaekek di Bandung, pasien Rumah Sakit Dewi Sri di Karawang dan pasien Rumah Sakit Delima Asih di Karawang. Dari segi pelayanan, kondisi yang dialami pasien hampir sama karena pasien tersebut seringkali melakukan pengobatan secara pribadi ke klinik milik dokter yang dituju.

Studi kuasi-eksperimental dilakukan dengan percobaan pada variabel untuk menentukan kemungkinan hubungan antara variabel satu dengan variabel lainnya. Studi kuasi-eksperimental dipilih karena telah menentukan kelompok kontrol dan kelompok eksperimen secara tidak acak. Menurut Sugiyono penelitian dalam eksperimen terbagi kepada beberapa bagian, diantaranya:

a) Pre-experimental design

Desain yang belum melakukan eksperimen dengan sungguh-sungguh karena masih ada pengaruhnya dari variabel luar.

b) True experimental design

Desain yang bisa dikatakan eksperimen yang sebenarnya karena peneliti dapat mengontrol semua variabel luar yang mempengaruhi jalannya eksperimen. Ciri utama dari eksperimen ini berupa sampel yang digunakan baik untuk kelompok kontrol maupun kelompok eksperimen diambil secara acak (random) dari populasi tertentu.

c) Quasi experimental design

Eksperimen yang memiliki perlakuan, pengukuran-pengukuran namun sampel yang digunakan tidak diambil secara acak. (Sugiyono, 2010)

Adapun jenis yang dipilih adalah kuasieksperimental desain kelompok kontrol nonsetara. Metode penelitian ini mengungkapkan hubungan sebab akibat dengan melibatkan kelompok kontrol dan kelompok eksperimen dengan tidak menggunakan teknik random. Desain penelitian ini menggunakan pre-test dan post-test yaitu membandingkan dua kelompok dan melihat perubahan yang terjadi terhadap kelompok tersebut. Penelitian dilakukan terhadap dua kelompok: kelompok kontrol dan kelompok eksperimen. Sementara pada kelompok eksperimen diberi perlakuan, berbeda dengan kelompok kontrol. Pada kelompok kontrol diberi post-test saja, sedangkan kelompok eksperimen mendapat pre-test dan post-test. Pre-test dilakukan sebelum pasien diberikan pengobatan untuk menentukan kondisi awal yang dialami oleh pasien.

Instrumen penelitian yang digunakan dalam pre-test dan post-test adalah angket pemahaman diri mengenai kondisi dan kekhawatiran yang dialami serta pedoman wawancara mengenai perubahan yang dialami setelah mengikuti bibliotherapy, yang membedakan adalah perlakuan terhadap kelompok kontrol dan kelompok eksperimen. Pada kelompok kontrol peneliti hanya memberi post-test saja, sedangkan untuk kelompok eksperimen, peneliti memberikan pre-test dan post-test. Kelompok eksperimen adalah kelompok yang mengikuti bibliotherapy, sedangkan kelompok kontrol tidak.

Kelompok kontrol terdiri dari 3 informan, diantaranya wanita hamil yang memiliki perasaan takut dan khawatir tentang persalinan alami atau operasi caesar karena keduanya memiliki resiko kematian, dan wanita menyusui yang selalu merasa stres dan takut salah dalam membesarkan anak sehingga menyebabkan ASI-nya tidak keluar, serta laki-laki yang pernah mengalami serangan jantung ringan yang selalu berhati-hati bahkan tidak pernah berolahraga karena takut terkena serangan jantung lagi. Sedangkan untuk kelompok eksperimen terdiri dari 3 orang informan, yakni wanita hamil yang memiliki ketakutan dan merasa khawatir berlebihan karena berdasarkan pengalaman saudaranya, meninggal setelah melahirkan anaknya, ibu menyusui yang mengalami baby blues syndrome sehingga tidak mau menyusui anaknya, serta bapak yang terkena gejala stroke yang memiliki ketakutan akan terkena stroke parah di masa yang akan datang. Informan dipilih karena memiliki kekhawatiran yang berlebihan terhadap sesuatu yang belum terjadi, 
maka melalui penelitian ini ingin membantu menumbuhkan sikap optimis pada para informan tersebut melalui bibliotherapy.

Tahap pertama adalah kelompok eksperimen diberi pre-test untuk menentukan kondisi awal yang dialami oleh pasien, pada fase ini pasien diberikan form dan mengisi formulir tersebut yang sesuai dengan kondisi pasien. Pasien diberi terapi dengan menggunakan metode bibliotherapy yang terdiri dari pemberian motivasi yang dilakukan oleh pustakawan, pasien diberi waktu untuk membaca buku di mana buku tersebut telah disiapkan oleh pustakawan, dan pasien diberikan waktu untuk refleksi diri setelah memahami isi buku tersebut, kemudian pustakawan mengadakan sebuah diskusi dengan pasien tentang masalah yang sedang dihadapi dan pustakawan menghubungkannya dengan isi buku dan yang terakhir adalah evaluasi yang dilakukan oleh seorang pustakawan yang bekerja sama dengan dokter untuk menentukan ada tidaknya perubahan yang terjadi pada informan dalam hal menumbuhkan sikap positif yang dimiliki.

Informan berada di berbagai rumah sakit karena di Indonesia rumah sakit masih jarang memiliki perpustakaan, kecuali sebuah rumah sakit besar saja. Di rumah sakit besar pun bibliotherapy tidak dijadikan layanan permanen perpustakaan dikarenakan kurangnya pengetahuan tentang peran pustakawan secara mendalam. Adapun data dikumpulkan dengan cara observasi, wawancara dan pengisian formulir. Kemudian data dianalisis menggunakan kualitatif dengan menggunakan ethical clearance, yakni penelitian kesehatan yang mengikutsertakan subyek manusia harus memperhatikan aspek etik dalam kaitan menaruh hormat atas martabat manusia. Secara hukum hal ini telah tersurat dalam PP 39/1995 tentang penelitian dan pengembangan kesehatan. Menurut PP tersebut, pelaksanaan penelitian dan pengembangan kesehatan wajib dilakukan dengan memperhatikan kesehatan dan keselamatan jiwa manusia, keluarga dan masyarakat yang bersangkutan. Secara internasional disepakati bahwa prinsip dasar penerapan etik penelitian kesehatan adalah menghargai informan, tanggung jawab untuk melakukan kebaikan yang menguntungkan pasien dan menghindari perbuatan yang merugikan atau membahayakan informan, tidak menyakiti informan, dan berlaku adil pada setiap informan ("Komisi Nasional Etik Penelitian Kesehatan," n.d.).

Waktu penelitian dilakukan selama setahun, karena proses menumbuhkan sikap optimis tidak dapat dilakukan dengan sekali terapi. Terapi tersebut dilakukan berulang-ulang tergantung dari kondisi mental setiap informan.

\section{HASIL DAN PEMBAHASAN}

Terapi dilakukan sebanyak 12 kali pertemuan mulai dari pre-test hingga post-test. Masing-masing informan diberi bacaan secara berkala yang disesuaikan dengan latar belakang pendidikan informan tersebut. Setiap bacaan yang diberikan dibagi kedalam 5 tahap, antara lain: Tahap 1: Pemberian motivasi, Tahap 2: Pemberian buku bacaan, yang mana setiap informan diharapkan membaca buku yang sudah ditentukan, Tahap 3: Refleksi diri, Tahap 4: Diskusi dan Tahap 5: Evaluasi

Hasil pretest menunjukkan bahwa pada kelompok eksperimen sedang dalam keadaan khawatir, dan ketakutan dari masalah yang dihadapi, seperti pada Tabel 1.

Pasien dalam kelompok eksperimen memiliki masalah yang berbeda, tapi dalam kondisi yang sama yakni merasa takut dan khawatir yang berlebihan. Penulis membuat janji dengan pasien dengan jadwal yang berbeda, mengingat harus menjaga kerahasiaan penyakit pasien. Adapun tahapan bibliotherapy nya antara lain:

Fase motivasi, tidak membedakan perlakuan yang diberikan. Sebelum melakukan pemberian motivasi, dipersiapkan segala sesuatu yang diperlukan untuk proses bibliotherapy, antara lain melakukan komunikasi persuasif kepada pasien agar pasien tersebut mau dengan ikhlas mengikuti bibliotherapy. Kemudian, menyiapkan bahan bacaan disesuaikan dengan kemampuan intelektual pasien. Untungnya pasien memiliki kemampuan intelektual yang sama, mereka masing-masing lulusan dari perguruan tinggi 
negeri jadi dengan mudah menyiapkan buku bacaan yang dirasa sesuai dengan masalah yang dihadapi para pasien. Adapun buku yang diberikan berupa cerita nyata tentang penyembuhan orang yang memiliki kanker, buku tentang gaya hidup sehat orang yang hidup dengan AIDS dalam rangka untuk meminimalkan penyakit dan kehidupan cerita dari orang-orang yang memiliki penyakit langka, hal ini bertujuan agar pasien dapat menumbuhkan semangat dalam dirinya untuk memulihkan dan merasa bersyukur bahwa ada banyak orang lain yang terkena penyakit yang lebih parah dari pasien. Pada fase ini, juga diberikan pre-test mengenai perasaan yang dialami, kondisi fisik yang dialami, dan hal-hal yang sedang dilakukan untuk menyingkirkan perasaan tersebut.

Fase kedua berupa proses membaca buku yang sudah disiapkan. Penulis merasa bahwa pasien sangat akrab dengan buku, hal tersebut berdasarkan penuturan pasien bahwa kerap mereka membaca novel, surat kabar ataupun komik di kehidupan sehari-harinya. Pasien diberikan waktu selama seminggu dikarenakan kesibukan jadwal yang berbeda. Pada tahap ini pasien dapat menuliskan poin-poin, yang tampaknya mewakili perasaan mereka, atau poin-poin penting yang dibahas. Selama seminggu, selalu dijaga kontak dengan pasien, sehingga merasa lebih diperhatikan

Proses selanjutnya adalah refleksi diri. Refleksi diri adalah kegiatan untuk merangsang pikiran pasien untuk dapat memikirkan hal-hal positif yang terkandung dalam buku tersebut. Pasien diberikan waktu selama seminggu untuk melakukan refleksi diri pada masalah yang dihadapi terkait dengan buku yang telah dibaca. Misalnya, pasien stroke setidaknya bisa sedikit bersyukur bahwa masih banyak orang yang terkena penyakit yang lebih berat seperti AIDS atau penyakit langka yang belum ditemukan obatnya. Pasien-pasien ini juga berpikir bahwa ada orang yang sembuh dari kanker yang terkenal mematikan, maka ia dengan gejala stroke yang dialami pasti bisa sembuh. Fase refleksi diri ini bisa menumbuhkan kepercayaan diri, semangat dan sikap optimis pada pasien meskipun hanya sedikit.
Setelah seminggu, pasien diajak untuk mendiskusikan isi buku dan membawa artikel dari koran tentang orang-orang yang sembuh dari penyakit dengan tujuan untuk memperkuat semangat, meyakinkan mereka bisa sembuh dan menumbuhkan sikap optimistis pasien. Pasien tidak dikumpulkan dalam satu ruangan keterkaitan dengan privasi pasien. Proses diskusi berjalan lama karena dalam proses tersebut diberikan kesempatan kepada pasien mengenai keluhan dan masalah yang dihadapi, dan selama proses diskusi, antusiasme pasien mengenai isi dari buku yang telah dibaca.

Tahap terakhir berupa evaluasi. Pasien diberikan post-test untuk menentukan perubahan pola pikir terutama sikap optimis. Selain itu pasien didampingi saat pemeriksaan dengan dokter sehingga dapat meminta bantuan dokter dalam hal mengevaluasi perubahan sikap optimis pasien. Adapun pertanyaan dari posttest sama dengan pertanyaan selama pre-test, untuk menentukan apakah ada perbedaan dari sebelum dan setelah terapi.

Bibliotherapy hanya pada kelompok eksperimen saja, sedangkan kelompok kontrol tidak. Hasil penelitian kuasi-eksperimental, dijelaskan dalam Tabel 2.

Berdasarkan Tabel 2, kelompok eksperimen lebih optimis dalam penyembuhan penyakitnya dibandingkan dengan kelompok kontrol, yang berarti bahwa bibliotherapy mempunyai pengaruh dalam penyembuhan pasien. Pada kelompok kontrol, telah dipilih tiga orang dengan penyakit yang sama yaitu wanita hamil dan ibu menyusui yang memiliki perasaan takut dan khawatir yang berlebihan, dan orangorang dengan penyakit jantung. Setiap pasien diperiksa berdasarkan 4 tingkat intervensi bibliotherapy, antara lain:

a) Intelektual: pasien dalam kelompok eksperimen telah memperoleh pengetahuan baru tentang penyakit mereka melalui buku yang disediakan oleh penulis. Dalam fase ini pasien mulai menyadari bahwa banyak pilihan solusi atas masalah-masalahnya. Contohnya wanita hamil yang selalu merasa takut dalam menghadapi persalinan diberikan pengetahuan baru mengenai jenis persalinan misalnya water birth, 
hypnobirth, dan lain-lain. Sedangkan, pada kelompok kontrol, pasien masih merasa takut dan khawatir tentang persalinan alami atau caesar karena mereka dapat menyebabkan kematian.

b) Sosial: Pada tingkat ini pasien tidak sendirian dalam menghadapi masalah, karena ada banyak orang yang mengalami hal yang sama bahkan lebih parah tapi bisa diobati. Misalnya ibu menyusui yang terkena baby blues syndrome, sehingga pasien tidak mau menyusui anaknya. Melalui bibliotherapy pasien ini menyadari bahwa ada ibu menyusui yang bahkan tega membunuh bayinya karena mereka merasa tidak mampu membesarkan anak, penyakit mental yang dialami ibu tersebut dapat disembuhkan tapi jika dibiarkan dapat membahayakan kehidupan bayi mereka. Setelah terapi melalui buku pasien tersebut sadar bahwa anak merupakan sesuatu yang berharga, yang bisa melanjutkan jejaknya di masa depan sehingga dia, mampu dan optimis bisa merawat anak-anak hingga anak-anak tersebut dewasa. Pada kelompok kontrol, pasien selalu merasa stres dan takut salah dalam membesarkan anak, menyebabkan ASI-nya tidak keluar. Maka anak-anak mereka hanya diberi susu formula yang manfaatnya jauh lebih sedikit dibandingkan dengan ASI.

c) Perilaku: Pada tingkat ini pasien telah menunjukkan sikap percaya diri dan memiliki tekad yang kuat untuk sembuh. Misalnya pada pasien dengan gejala stroke setelah dilakukan terapi pasien tersebut memiliki kepercayaan diri untuk sembuh dan akan mencoba berbagai pengobatan medis atau alternatif dan merubah gaya hidup menjadi lebih sehat. Pada kelompok kontrol, pria yang menderita penyakit jantung selalu sangat berhati-hati untuk tidak melakukan olahraga karena takut penyakit jantung nya kambuh lagi. Padahal bukan olahraga yang memicu penyakit jantung, akan tetapi pola hidup yang kurang sehat.

d) Emosional: pasien kelompok eksperimen setelah melakukan terapi, masing-masing memiliki keyakinan dan sikap optimis dalam menghadapi masalah yang sedang dialami. Berbeda dengan kelompok kontrol yang tidak melakukan terapi, kelompok ini terkena rasa takut dan khawatir tentang masalah-masalah yang dialami mereka dan jika hal ini terus dibiarkan malah akan memperburuk kesehatan mereka.

Ada perbedaan yang terlihat antara kelompok eksperimen diberi perlakuan dengan kelompok kontrol yang tidak menerima pengobatan, perbedaan dapat dilihat dalam hal perilaku intelektual, sosial, emosional dari masingmasing kelompok.

Berdasarkan penjelasan di atas, dapat dibuktikan bahwa bibliotherapy bermanfaat dalam menumbuhkan sikap optimis pada pasien sehingga pasien bisa menghadapi masalah yang diderita. Kedepannya bisa membuat bibliotherapy menjadi salah satu layanan yang dapat diimplementasikan di perpustakaan rumah sakit yang bekerja sama dengan dokter mengobati pasien yang bersangkutan.

\section{E. KESIMPULAN}

Bibliotherapy adalah salah satu teknik penyembuhan mental, terutama ketakutan, kecemasan dan stres. Dalam pelaksanaan bibliotherapy pustakawan dapat bekerjasama dengan dokter di rumah sakit. Bibliotherapy dapat diimplementasikan dalam ruang perpustakaan yang tenang sehingga pasien dapat merasa santai dan tidak tegang. Bibliotherapy dapat diimplementasikan pada pasien yang memiliki riwayat penyakit yang berbeda dan sebaliknya berhasil mengubah pola pikir pasien berkembang ke arah positif sehingga dapat membantu proses penyembuhan pasien tersebut. Adapun saran yang dapat diimplementasikan, adalah setiap rumah sakit harus memiliki perpustakaan untuk meningkatkan kinerja rumah sakit serta untuk menambah pengetahuan dan hiburan bagi pasien yang berkunjung karena ada banyak rumah sakit di Indonesia yang belum memiliki perpustakaan dengan alasan kekurangan dana. Bibliotherapy sebaiknya dilaksanakan di setiap rumah sakit karena terbukti membantu dalam proses penyembuhan pasien. Bibliotherapy 
dapat menjadi salah satu layanan yang diberikan oleh perpustakaan. Bibliotherapy dapat dilakukan dengan pustakawan dan evaluasi yang dilakukan oleh seorang dokter yang bekerja sama dengan pustakawan, penting dilakukan kerjasama antara dokter dan pustakawan dalam hal bibliotherapy agar bisa memutuskan hasil bibliotherapy secara akurat.

\section{DAFTAR PUSTAKA}

Agustina, S. (2014). Perpustakaan sebagai wahana terapi yang ramah disabilitas: Jurnal Edulib, 1(2), 122-146.

Anggraeni, A. (2018). Biblioterapi untuk meningkatkan pemahaman labelling negatif pada siswa SMP. Jurnal Bikotetik: Bimbingan Konseling Teori dan Praktek, 2(1), 109-114.

Bibliotherapy: online dictionary for library and information science. (n.d.). Retrieved August 4, 2018, from https://www.abcclio.com/ODLIS/odlis_b.aspx\# bibliotherapy

Chandra, A. (2011, August 6). Inilah 10 keuntungan "positive thinking." Kompas.com. Retrieved from https:// lifestyle.kompas.com/read/2011/08/06/10 050416/Inilah.10.Keuntungan.Positive.Thi nking. Diakses pada tanggal 06 Agustus 2018.

Darmawan, W., Rohanda, \& Kusnandar. (2012). Penerapan biblioterapi di Rumah Sakit Dr. Cipto Mangunkusumo. E-jurnal Mahasiswa Universitas Padjadjaran, 1(1), $1-19$.

Dewi, N., \& Prihartanti, N. (2014). Metode biblioterapi dan diskusi dilema moral untuk pengembangan karakter tanggungjawab. Jurnal Psikologi, 41(1), 47-59.

Eliasa, E. I., \& Iswanti, S. (2014). Bibliotherapy with the career topic to increase the student's career motivation of guidance and counseling. Procedia Journal - Social and Behavioral Sciences, 114(8), 1-5. Retrieved from https://ac.els-cdn.com/ S1877042813053640/1-s2.0-S187704281 3053640-main.pdf?_tid=03d38be9-026d4614-87a8-0d5d80aa0b71\&acdnat $=$ 1531993376 c5450f8c6de6eba58e5cbb49 $5 b 29777 \mathrm{c}$
Gil. (2013). Kisah kanker: Jangan menyerah pada penyakit ini, aku bisa sembuh. Retrieved July 4, 2017 , from https://www.vemale.com/kesehatan/31149 -kisah-kanker-jangan-menyerah-padapenyakit-ini-aku-bisa-sembuh.html

Herlina. (2013). Bibliotherapy: Mengatasi masalah anak dan remaja melalui buku. Bandung: Pustaka Cendekia Utama.

Jack, S. J., \& Ronan, K. R. (2008). Bibliotherapy practice and research. SAGE Journals, 29(2), 161-182.

Komisi Nasional Etik Penelitian Kesehatan. (n.d.). Retrieved August 4, 2018, from http://www.knepk.litbang.depkes.go.id/kn epk/

Magaji, \& Shem. (2016). Bibliotherapy as a problem-solving skill of counsellors and teachers for character and skills development in Ogun State, Nigeria. Journal of Education and Practice, 7(20), 18-22.

Manwell, L. A., Barbic, S. P., Roberts, K., Dusrisko, Z., Lee, C., Ware, E., \& Mckenczi, K. (2015). What is mental health? Evidence towards a new definition from a mixed methods multidisciplinary international survey. BMJ Open Journal, 5(6), 1-11. https://doi.org/10.1136/ bmjopen-2014-007079

Maydiana, T., \& Siswanto, S. (2012). Efektivitas bibliotherapy untuk mengurangi kecemasan pada penderita kanker. Vitashpere: Jurnal Manajemen Kualitas Hidup, 2(1), 72-77.

Novita, K. R., Sugiharto, D. Y., \& Ani, C. T. (2017). Meningkatkan kemampuan prososial siswa SD melalui layanan informasi dengan teknik bibliotherapy. IJGC: Indonesian Journal of Guidance and Counseling, 6(4), 42-49.

Olsen, M. A. (2007). Bibliotherapy: School psychologys report of use and efficacy. Brigham: Brigham Young University.

Pittman, B. (2017). Bibliotherapy: From library war service to science. Retrieved August 4, 2018, from https://blogs.lib.uconn.edu/ archives/2017/04/12/bibliotherapy-fromlibrary-war-service-to-science/ 
Sugiyono. (2010). Metode penelitian kuantitatif, kualitatif dan $R \& D$. Bandung: Alfabeta.

Yuliawati, R. (2011). Bimbingan dan konseling berbasis layanan bibliotherapy: Upaya sekolah dalam pengembangan perpustakaan. Visi Pustaka, 13(3). R e t r i e v e d f r o m h t t p / / dev.perpusnas.go.id/magazine/layananbimbingan-dan-konseling-berbasisbibli ot e rapi-sebuah - up a y pengembangan-perpustakaan-sekolah/. Diakses pada tanggal 12 Juli 2018. 


\section{DAFTAR GAMBAR}

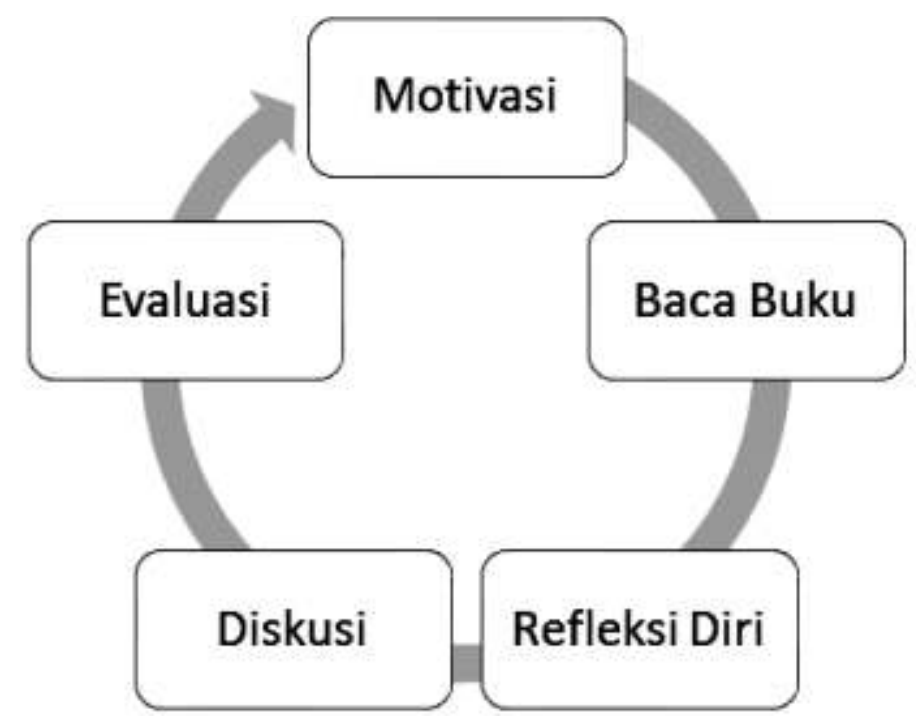

Gambar 1. Lingkaran Bibliotheraphy Marci A Olsen

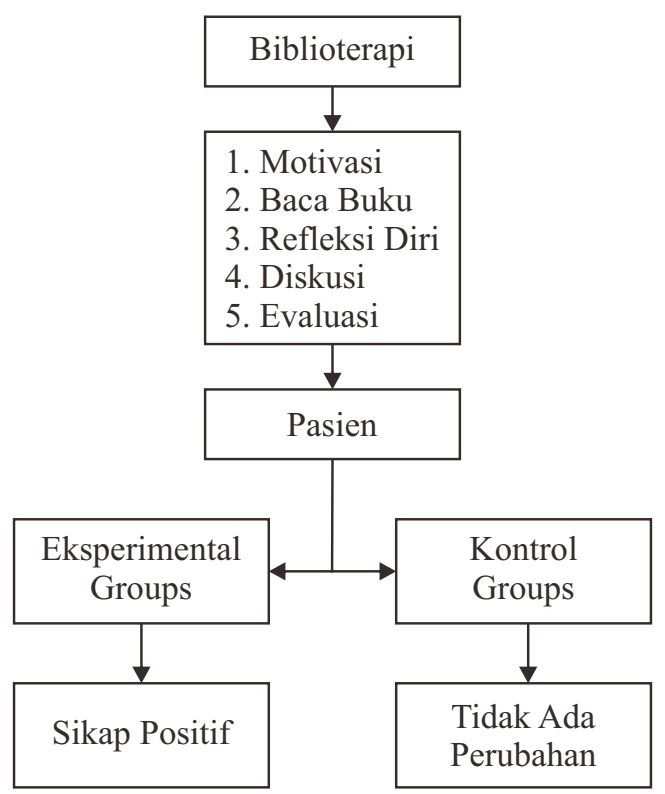

Gambar 2. Kerangka Penelitian 


\section{DAFTAR TABEL}

Tabel 1. Hasil Pretest Pada Kelompok Eksperimental

\begin{tabular}{lll}
\hline No & Pasien & Kondisi \\
\hline 1. & Wanita hamil & $\begin{array}{l}\text { Ketakutan dan merasa khawatir berlebihan karena berdasarkan } \\
\text { pengalaman saudaranya, meninggal setelah melahirkan anaknya. }\end{array}$ \\
\hline 2. & Ibu menyusui & $\begin{array}{l}\text { Mengalami baby blues syndrome sehingga tidak mau menyusui } \\
\text { anaknya. }\end{array}$ \\
\hline 3. & Bapak yang terkena gejala stroke & Takut stroke yang dialaminya bertambah parah. \\
\hline
\end{tabular}

Sumber: hasil penelitian, 2015

Tabel 2. Hasil Penelitian

\begin{tabular}{|c|c|c|c|c|c|}
\hline \multirow[t]{2}{*}{ No } & \multirow[t]{2}{*}{ Patients } & \multicolumn{2}{|c|}{ Eksperimental groups } & \multicolumn{2}{|c|}{ Kontrol groups } \\
\hline & & Pretest & Posttest & Pretest & Posttest \\
\hline 1. & Wanima hamil & $\begin{array}{l}\text { Ketakutan dan } \\
\text { merasa khawatir } \\
\text { berlebihan karena } \\
\text { berdasarkan } \\
\text { pengalaman } \\
\text { saudaranya, } \\
\text { meninggal setelah } \\
\text { melahirkan } \\
\text { anaknya. }\end{array}$ & $\begin{array}{l}\text { Sudah jauh lebih } \\
\text { tenang, merasa siap } \\
\text { dan senang } \\
\text { menyambut bayi, } \\
\text { dan kematian pasti } \\
\text { terjadi pada siapa } \\
\text { saja, bukan hanya } \\
\text { ketika melahirkan. }\end{array}$ & & $\begin{array}{l}\text { Takut dan } \\
\text { khawatir tentang } \\
\text { persalinan alami } \\
\text { atau operasi } \\
\text { caesar. Karena } \\
\text { keduanya } \\
\text { memiliki resiko } \\
\text { kematian. }\end{array}$ \\
\hline 2. & Ibu Menyusui & $\begin{array}{l}\text { Mengalami baby } \\
\text { blues syndrome } \\
\text { sehingga tidak } \\
\text { mau menyusui } \\
\text { anaknya. }\end{array}$ & $\begin{array}{l}\text { Pola pikir mulai } \\
\text { terbuka, perasaan } \\
\text { yang kuat dan } \\
\text { bahagia karena dia } \\
\text { memiliki keyakinan } \\
\text { bahwa tidak semua } \\
\text { orang mempunyai } \\
\text { kesempatan untuk } \\
\text { melahirkan anak. }\end{array}$ & & $\begin{array}{l}\text { Selalu merasa } \\
\text { stres dan takut } \\
\text { salah dalam } \\
\text { membesarkan } \\
\text { anak sehingga } \\
\text { menyebabkan } \\
\text { ASI-nya tidak } \\
\text { keluar }\end{array}$ \\
\hline 3. & $\begin{array}{l}\text { Laki-laki dengan } \\
\text { gejala stroke (Kel. } \\
\text { Eksperimental) }\end{array}$ & $\begin{array}{l}\text { Takut stroke yang } \\
\text { dialaminya } \\
\text { bertambah parah }\end{array}$ & $\begin{array}{l}\text { Berbesar hati } \\
\text { menghadapi } \\
\text { kenyataan dan } \\
\text { mempunyai sikap } \\
\text { optimis bahwa ia } \\
\text { bisa sembuh dengan } \\
\text { mengubah gaya } \\
\text { hidup seperti } \\
\text { olahraga dan pola } \\
\text { makan yang sehat }\end{array}$ & & \\
\hline 4 & $\begin{array}{l}\text { Laki-laki yang pernah } \\
\text { mengalami serangan } \\
\text { jantung ringan }\end{array}$ & & & & $\begin{array}{l}\text { Selalu berhati-hati } \\
\text { bahkan tidak } \\
\text { pernah } \\
\text { berolahraga } \\
\text { karena takut } \\
\text { terkena serangan } \\
\text { jantung lagi. }\end{array}$ \\
\hline
\end{tabular}

Sumber: hasil penelitian, 2015 